\title{
Transfer of transuranium elements along the food chain pÿlichen-reindeer-man A review of investigations in Finnish Lapland
}

\section{Paatero, Jussi}

2020-02

Paatero , J \& Salminen-Paatero, S 2020 , ' Transfer of transuranium elements along the pÿfood chain lichen-reindeer-man A review of investigations in Finnish Lapland ', Journal of Environmental Radioactivity , vol. 212 , 106126 . https://doi.org/10.1016/j.jenvrad.2019.106126

http://hdl.handle.net/10138/337144

https://doi.org/10.1016/j.jenvrad.2019.106126

acceptedVersion

Downloaded from Helda, University of Helsinki institutional repository.

This is an electronic reprint of the original article.

This reprint may differ from the original in pagination and typographic detail.

Please cite the original version. 


\title{
Transfer of transuranium elements along the food chain lichen-reindeer-man - A review of investigations in Finnish Lapland
}

\author{
Jussi Paatero $^{\mathrm{a}, *}$, Susanna Salminen-Paatero ${ }^{\mathrm{a}, \mathrm{b}}$

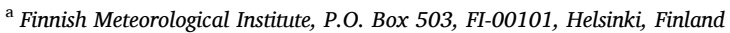 \\ ${ }^{\mathrm{b}}$ Department of Chemistry, Radiochemistry, P.O. Box 55, FI-00014, University of Helsinki, Finland
}

\section{A R T I C L E I N F O}

\section{Keywords:}

Finland

Lichen

Reindeer

Plutonium

Americium

\begin{abstract}
A B S T R A C T
Following the atmospheric nuclear tests in the ' 50 s and early ' 60 s radioecological research on the (sub)arctic food chain lichen-reindeer/caribou-man was initiated in Finland among other northern countries. The enrichment of radionuclides in this food chain can lead to exceptionally high body burdens among the indigenous Sami and Inuit populations consuming large quantities of the meat and edible organs of reindeer and caribou.

In Finland, first fission and activation products and natural radionuclides were studied but in the early $1970 \mathrm{~s}^{\prime}$ the investigations concerning transuranium elements were started. These studies have continued to the present as also the effects of the Chernobyl accident on the existence of neptunium, plutonium, americium and curium isotopes in the environment of northern Finland have been investigated. In addition to radioactivity measurements detailed dietary surveys were performed among the reindeer herders and other Sami persons to assess the human intake of radionuclides by ingestion.

The main aim of this literature review is to summarize the obtained data concerning transuranium elements in the food chain lichen-reindeer-man in northern Finland but also some supporting data is included.
\end{abstract}

\section{Introduction}

Considerable amounts of man-made radioactivity have been transported to the Arctic environment since the start of the nuclear era in 1945. There has been a variety of sources contributing to this: nuclear weapons tests, the 1986 Chernobyl accident, liquid and atmospheric emissions from the nuclear fuel reprocessing plants in Sellafield and Dounreay, the United Kingdom, La Hague, France, operational and accidental liquid and atmospheric emissions from the nuclear weapons production and fuel reprocessing facilities in Russia (Chelyabinsk, Tomsk and Krasnoyarsk), Soviet dumping of nuclear waste and used reactors to the Arctic Ocean. Local contamination has occurred due to accidents involving aircrafts carrying nuclear weapons, nuclear-powered vessels and the handling of their fuel cycle. Especially important of these has been the Novaya Zemlya nuclear test site. The Soviet Union conducted there 91 nuclear tests in the atmosphere, ground surface and water in 1955-1962 including the most powerful atmospheric nuclear test ever ("Tsar Bomba" or "Big Ivan", 50-58 megatons) on October 30, 1961 (Arctic Monitoring and Assessment Programme, 2010). The most recent significant source of artificial radioactivity transported to the Arctic is the 2011 Fukushima accident (Paatero et al., 2012).
Finnish Lapland has received radioactivity from the nuclear weapons tests, Chernobyl and Fukushima nuclear accidents and the 1964 SNAP9A satellite re-entry accident (Krey, 1967). The radionuclides deposited included also transuranium elements plutonium, americium, curium, and neptunium. The environmental behaviour of these elements is important to know for several reasons. Most of them are alpha emitters and thus highly radiotoxic. Many of them have long physical and biological half-lives. And finally, large amounts of these elements are formed in nuclear explosions and during the operation of nuclear reactors.

Following the atmospheric nuclear tests in the '50s and early ' $60 \mathrm{~s}$ several radioecological research projects, focused on the (sub)arctic food chain lichen-reindeer/caribou-man, were initiated in Scandinavia and North America (Miettinen et al., 1963; Svensson and Liden, 1965; Hanson, 1967; Holm \& Persson, 1975, 1978a). Lichen collects deposited radionuclides efficiently and is the main fodder for reindeer during the winter season (Tuominen and Jaakkola, 1973). In summer and autumn reindeer eat mostly grass, birch leaves and mushroom (Rissanen and Rahola, 1989). The enrichment of radionuclides in this food chain can lead to exceptionally high body burdens among the indigenous Sami and Inuit (Eskimo) populations consuming large quantities of the meat and

\footnotetext{
* Corresponding author.

E-mail addresses: jussi.paatero@fmi.fi (J. Paatero), susanna.salminen-paatero@helsinki.fi (S. Salminen-Paatero).
} 
Table 1

Radioanalytical methods used for determining transuranium radionuclides in Finnish radioecological studies.

\begin{tabular}{|c|c|c|c|}
\hline $\begin{array}{l}\text { Transuranium } \\
\text { element }\end{array}$ & Separation method & Detection method & Reference \\
\hline \multirow[t]{8}{*}{$\mathrm{Pu}$} & ashing and/or acid digestion anion exchange & Alpha spectrometry $\left({ }^{238} 239^{, 240} \mathrm{Pu}\right)$ & $\begin{array}{l}\text { Tulikoura et al. (1974); } \\
\text { Jaakkola et al. (1975); } \\
\text { Miettinen (1976); Keinonen et al. } \\
\text { (1977); } \\
\text { Miettinen et al. (1980); } \\
\text { Hakanen (1981); } \\
\text { Jaakkola et al. (1981); Hakanen et al. } \\
\text { (1984); } \\
\text { Mussalo-Rauhamaa (1981); } \\
\text { Mussalo-Rauhamaa et al. (1984) }\end{array}$ \\
\hline & & Liquid scintillation counting $\left({ }^{241} \mathrm{Pu}\right)$ & Hakanen et al. (1984) \\
\hline & $\begin{array}{l}\text { acid digestion calcium oxalate and iron hydroxide co- } \\
\text { precipitations } \\
\text { anion exchange }\end{array}$ & Alpha spectrometry $\left({ }^{238} 239^{, 240} \mathrm{Pu}\right)$ & $\begin{array}{l}\text { Paatero et al. (1998); Paatero and } \\
\text { Jaakkola (1998) }\end{array}$ \\
\hline & & Liquid scintillation counting $\left({ }^{241} \mathrm{Pu}\right)$ & Paatero et al. (1994) \\
\hline & & SF-ICP-MS $\left({ }^{240} \mathrm{Pu} /{ }^{239} \mathrm{Pu}\right)$ & Salminen-Paatero et al. (2012) \\
\hline & ashing acid digestion extraction chromatography & Alpha spectrometry $\left({ }^{238} 239^{, 240} \mathrm{Pu}\right)$ & $\begin{array}{l}\text { Salminen and Paatero (2009); } \\
\text { Salminen-Paatero et al. (2019) }\end{array}$ \\
\hline & & Liquid scintillation counting $\left({ }^{241} \mathrm{Pu}\right)$ & \\
\hline & & SF-ICP-MS $\left({ }^{240} \mathrm{Pu} /{ }^{239} \mathrm{Pu}\right)$ & Salminen-Paatero et al. (2012) \\
\hline \multirow[t]{6}{*}{ Am $\mathrm{Cm}$} & $\begin{array}{l}\text { ashing and/or acid digestion ion exchange solvent } \\
\text { extraction }\end{array}$ & Alpha spectrometry $\left({ }^{241} \mathrm{Am}\right)$ & $\begin{array}{l}\text { Miettinen et al. (1980); Jaakkola } \\
\text { et al. (1981) }\end{array}$ \\
\hline & $\begin{array}{l}\text { ashing and/or acid digestion calcium oxalate and iron } \\
\text { hydroxide co-precipitations } \\
\text { solution }\end{array}$ & Alpha spectrometry $\left({ }^{241} \mathrm{Am},{ }^{242} 243,244 \mathrm{Cm}\right)$ & $\begin{array}{l}\text { Paatero et al. (1998); Paatero and } \\
\text { Jaakkola (1998) }\end{array}$ \\
\hline & $\begin{array}{l}\text { ashing acid digestion calcium oxalate and iron hydroxide } \\
\text { co-precipitations anion exchange extraction } \\
\text { chromatography }\end{array}$ & Alpha spectrometry $\left({ }^{241} \mathrm{Am},{ }^{242} 243^{, 244} \mathrm{Cm}\right)$ & Salminen et al. (2005) \\
\hline & ashing acid digestion extraction chromatography & Alpha spectrometry $\left({ }^{241} \mathrm{Am}\right)$ & Salminen et al. (2009) \\
\hline & & Alpha spectrometry of old $\mathrm{Pu}$ alpha samples, for & Harva (1976); \\
\hline & & determining ${ }^{241} \mathrm{Pu}$ via ingrowth of ${ }^{241} \mathrm{Am}$ & Salminen-Paatero et al. (2014) \\
\hline \multirow[t]{2}{*}{$\mathrm{Np}$} & $\begin{array}{l}\text { ashing acid digestion oxalate precipitation extraction } \\
\text { chromatography }\end{array}$ & SF-ICP-MS $\left({ }^{237} \mathrm{~Np}\right)$ & Salminen et al. (2009) \\
\hline & & Gamma spectrometry $\left({ }^{239} \mathrm{~Np}\right)$ & Rantavaara (1987) \\
\hline
\end{tabular}

edible organs of reindeer and caribou.

The Department of Radiochemistry, University of Helsinki, started the studies on lichen-reindeer-man food chain in the beginning of the 1960s. First fission products were studied (Salo et al., 1963; Miettinen and Hasanen, 1967) but when the United States Atomic Energy Commission (AEC) started to finance the studies also activation products (Jaakkola, 1969), natural radionuclides (Kauranen and Miettinen, 1969) and, in the early 1970s, transuranium nuclides were investigated (Tulikoura et al., 1974; Jaakkola et al., 1975, 1978). Altogether AEC and its successors, United States Energy Research and Development Administration and United States Department of Energy, funded these studies nicknamed "American project" for thirteen years, a rare case in the Finnish history of science. In addition to radioactivity measurements detailed dietary surveys were performed to assess the human intake of radionuclides by ingestion (Jokelainen et al., 1962; Jokelainen, 1965; Hasunen and Mottonen, 1976).

The main aim of this literature review is to summarize the obtained data concerning transuranium elements in the food chain lichenreindeer-man in northern Finland but also some supporting data is included. A brief summary of the radioanalytical methods used in these studies is presented in Table 1.

\section{Deposition of transuranium elements}

According to Paatero et al. (2010) the strontium-90 $\left({ }^{90} \mathrm{Sr}\right.$ ) global fallout from the atmospheric nuclear test was quite evenly distributed in Finland with only a slight downward trend from south to north. The deposition represented also well the zonal ${ }^{90} \mathrm{Sr}$ deposition between the 60th and the 70th latitude. The deposition of ${ }^{90} \mathrm{Sr}$ in northernmost Lapland was about $1 \mathrm{kBq} / \mathrm{m}^{2}$. Based on the measured ratio of plutonium-239,240 $\left({ }^{239,240} \mathrm{Pu}\right)$ to ${ }^{90} \mathrm{Sr}, 0.01763$, it can be estimated that the ${ }^{239,240} \mathrm{Pu}$ deposition was about $20 \mathrm{~Bq} / \mathrm{m}^{2}$. On the other hand, Hardy et al. (1973) give a zonal ${ }^{239,240} \mathrm{Pu}$ deposition value of about $60 \mathrm{~Bq} / \mathrm{m}^{2}$ between the 60 th and the 70th latitude and $13 \mathrm{~Bq} / \mathrm{m}^{2}$ between the 70th and the 80th latitude, in other words, of the same order of magnitude (Fig. 1). The ${ }^{239,240} \mathrm{Pu}$ deposition from the 1986 Chernobyl accident was about $0.1 \mathrm{~Bq} / \mathrm{m}^{2}$ in Inari (Paatero et al., 1998). Only Halla, the southernmost reindeer herding district in Finland, east of Kajaani next to the Finnish-Russian border (Fig. 2), received considerable amounts of deposited radionuclides from the Chernobyl accident.

Assuming that the ${ }^{239,240} \mathrm{Pu}$ deposition due to nuclear tests was 20 $\mathrm{Bq} / \mathrm{m}^{2}$ we can calculate, based on activity ratios that the deposition of neptunium-237 $\left({ }^{237} \mathrm{~Np}\right),{ }^{238} \mathrm{Pu}$, and ${ }^{241} \mathrm{Pu}$ was $0.07,0.6$ and $320 \mathrm{~Bq} / \mathrm{m}^{2}$, respectively, in northern Lapland. The above mentioned burning of the SNAP-9A ${ }^{238} \mathrm{Pu}$ power source after the satellite re-entry increased the ${ }^{238} \mathrm{Pu}$ deposition to $1.3 \mathrm{~Bq} / \mathrm{m}^{2}$. The Chernobyl accident increased the ${ }^{237} \mathrm{~Np},{ }^{241} \mathrm{Am},{ }^{238} \mathrm{Pu}$ and ${ }^{241} \mathrm{Pu}$ deposition with $0.0000125,0.045,0.05$ and 9.5 Bq/ $\mathrm{m}^{2}$, respectively (Paatero et al., 1994, 2002; Salminen et al., 2009). The Chernobyl-derived ${ }^{244} \mathrm{Cm}$ deposition north of the Arctic Circle was less than $0.023 \mathrm{~Bq} / \mathrm{m}^{2}$ (Salminen et al., 2005).

\section{Plutonium}

The activity concentration of plutonium isotopes 239 and 240 in lichen in Lapland was about $4 \mathrm{~Bq} / \mathrm{kg}$ dry weight (d.w.) in 1960-1962 (Fig. 3). Due to the intense nuclear testing just before the Partial Test Ban Treaty in 1963 the concentration level rose to $9 \mathrm{~Bq} / \mathrm{kg}$ but returned to the $4 \mathrm{~Bq} / \mathrm{kg}$ level in 1965 . This level was maintained for several years by the atmospheric nuclear tests of the People's Republic of China. Following the Chernobyl accident the ${ }^{239,240} \mathrm{Pu}$ activity concentration in lichen was $0.306 \mathrm{~Bq} / \mathrm{kg}$ d.w. in 1986 and $0.07 \mathrm{~Bq} / \mathrm{kg}$ d.w. one year later (Paatero et al., 1998). The activity concentration of ${ }^{241} \mathrm{Pu}$ varied between 110 and $1.5 \mathrm{~Bq} / \mathrm{kg}$ d.w. in lichen between 1960 and 1976. In 1987 the ${ }^{241} \mathrm{Pu}$ activity concentration had dropped below the detection limit 


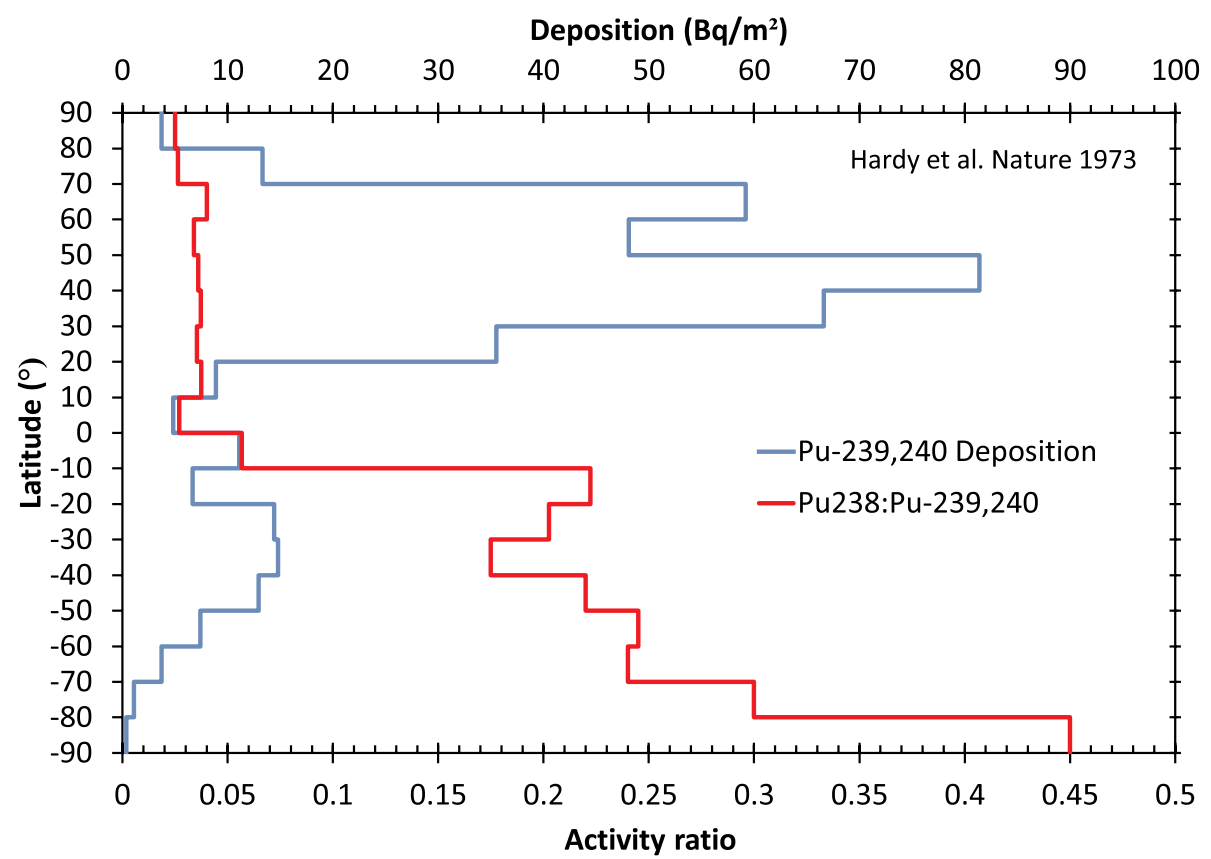

Fig. 1. Deposition of ${ }^{239,240} \mathrm{Pu}$ and ${ }^{238} \mathrm{Pu}:{ }^{239,240} \mathrm{Pu}$ activity ratio as a function of latitude (Data from Hardy et al., 1973). Finland is located between the 60 th and the 70th latitude North.

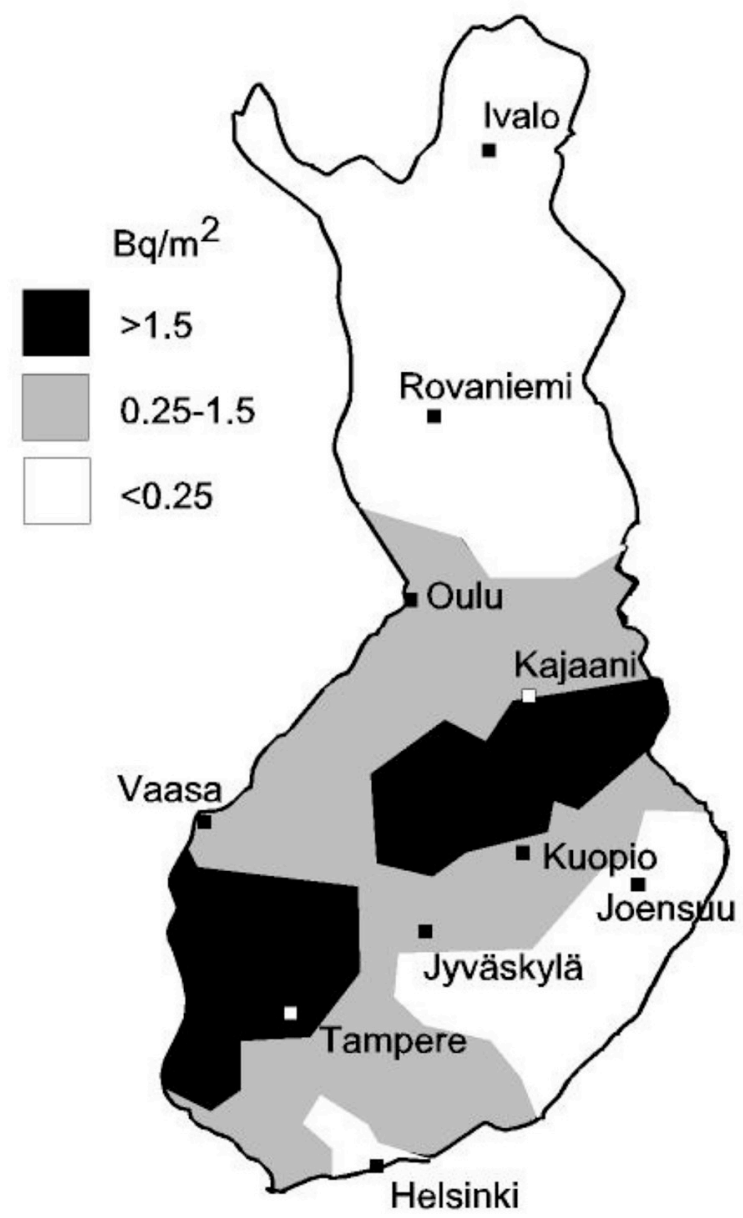

Fig. 2. Deposition of ${ }^{239,240} \mathrm{Pu}$ in Finland after the 1986 Chernobyl accident (Paatero et al., 2006). of $1.4 \mathrm{~Bq} / \mathrm{kg}$. For comparison, a lichen sample from south-western Finland contained $5.7 \quad 0.3 \mathrm{~Bq} / \mathrm{kg}$ d.w. of ${ }^{239,240} \mathrm{Pu}$ and another sample $20411 \mathrm{~Bq} / \mathrm{kg}$ d.w. of ${ }^{241} \mathrm{Pu}$ (Hakanen et al., 1984; Paatero et al., 1994). A similar temporal behaviour was observed with birch leaves and grass which are important reindeer fodder in summer (Fig. 4). The maximum concentration level in tree lichen (Alectoria sp.), $17 \mathrm{~Bq} / \mathrm{kg} \mathrm{d}$. w., was observed in 1966, in other words, three years later than the maximum deposition occurred. This may be related to the slow accumulation of radionuclides into tree lichen.

The ${ }^{238} \mathrm{Pu} /{ }^{239,240} \mathrm{Pu}$ activity ratio was around $3 \%$ in the early 1960 s, a typical value for plutonium originating from global weapons test fallout (Fig. 5). Owing to the 1964 SNAP-9A accident the activity ratio increased gradually after the year 1965 to about $8 \%$. The interhemispheric transport of air masses is relatively slow and it took two years from the SNAP-9A ${ }^{238} \mathrm{Pu}$ to reach Finnish Lapland (Miettinen, 1976). The 1986 Chernobyl accident didn't increase the activity ratio in Finnish Lapland. However, in southern Finland the ratio increased to 50\%. The ${ }^{238} \mathrm{Pu} /{ }^{239,240} \mathrm{Pu}$ activity ratio was $5 \%$ in top parts and $9 \%$ in lower parts of two lichens collected in Inari in 1976 indicating a downward migration of SNAP-9A ${ }^{238} \mathrm{Pu}$ in lichen thallus (Salminen-Paatero et al., 2014). In the same lichens another $\mathrm{Pu}$ activity ratio, namely ${ }^{241} \mathrm{Pu} /{ }^{239}{ }^{240} \mathrm{Pu}$, didn't differ between top and lower parts, the ratio being 7.3-8.5 in all parts. These values for ${ }^{241} \mathrm{Pu} /{ }^{239}{ }^{240} \mathrm{Pu}$ ratio are typical for global nuclear weapons testing fallout in 1970's. Third isotope ratio that acts as an indicator of nuclear contamination sources, mass ratio ${ }^{240} \mathrm{Pu} /{ }^{239} \mathrm{Pu}$, has been determined from air filters collected in Sodankyla in 1963 and in Rovaniemi in 1965-2011. Mass ratio ${ }^{240} \mathrm{Pu} /{ }^{239} \mathrm{Pu}$ was $0.14-0.37$ in surface air of Sodankyla during the year of deposition maximum from atmospheric nuclear weapons testing (Salminen-Paatero et al., 2012). In the surface air of Rovaniemi, the ratio had the minimum value of 0.117 in 1981 and the maximum value of 0.278 in April-June 1986 (Salminen-Paatero et al., 2019). The mass ratio in air has presumably been the same as in deposition accumulation to lichens of the same area after few years. Most of the ${ }^{240} \mathrm{Pu} /{ }^{239} \mathrm{Pu}$ mass ratio values in Sodankyla during 1963 and in Rovaniemi 1965-2011 were on the same level as the ratio is in global fallout from nuclear weapons testing.

Biological half-lives of radionuclides are an important factor 


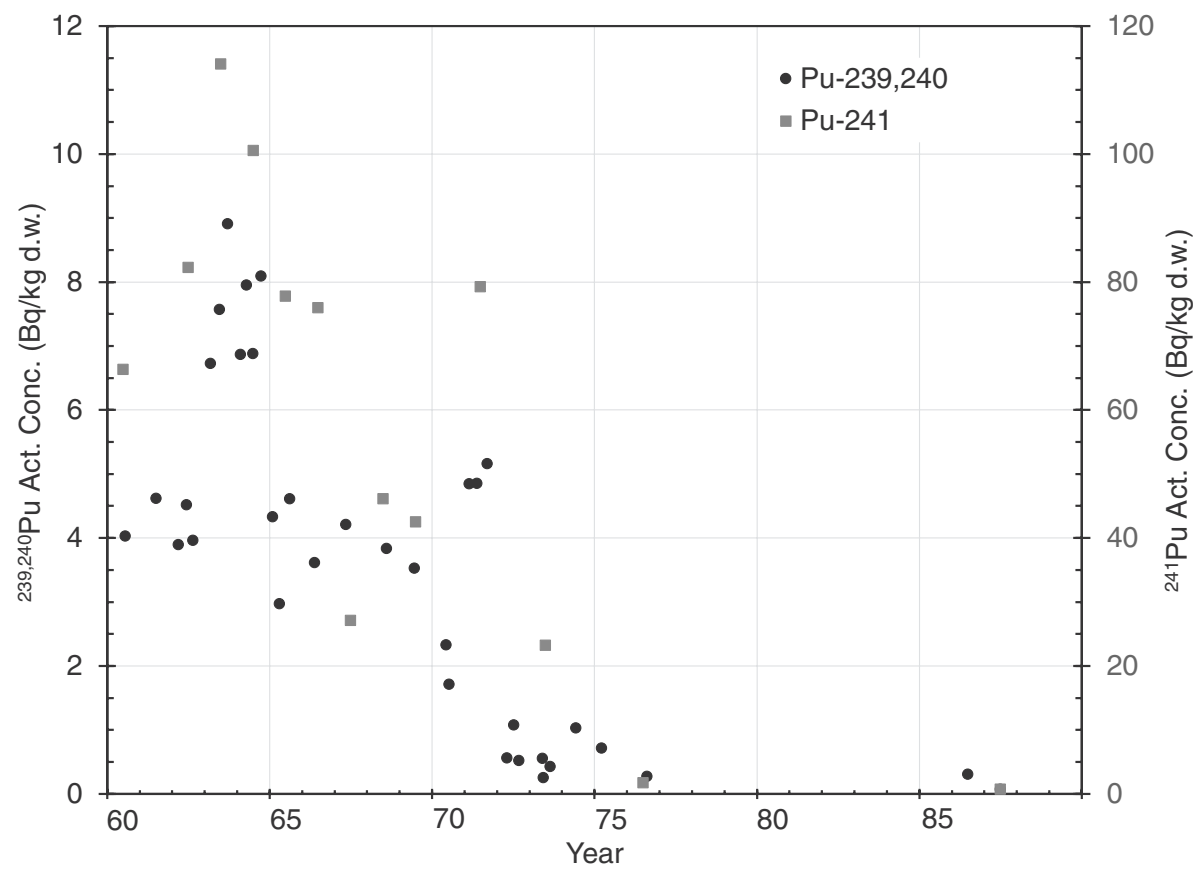

Fig. 3. ${ }^{239,240} \mathrm{Pu}$ (left vertical axis, black discs) and ${ }^{241} \mathrm{Pu}$ (right vertical axis, grey squares) in lichen in Finnish Lapland during 1960-1987 (Jaakkola et al., 1981; Paatero et al., 1998).

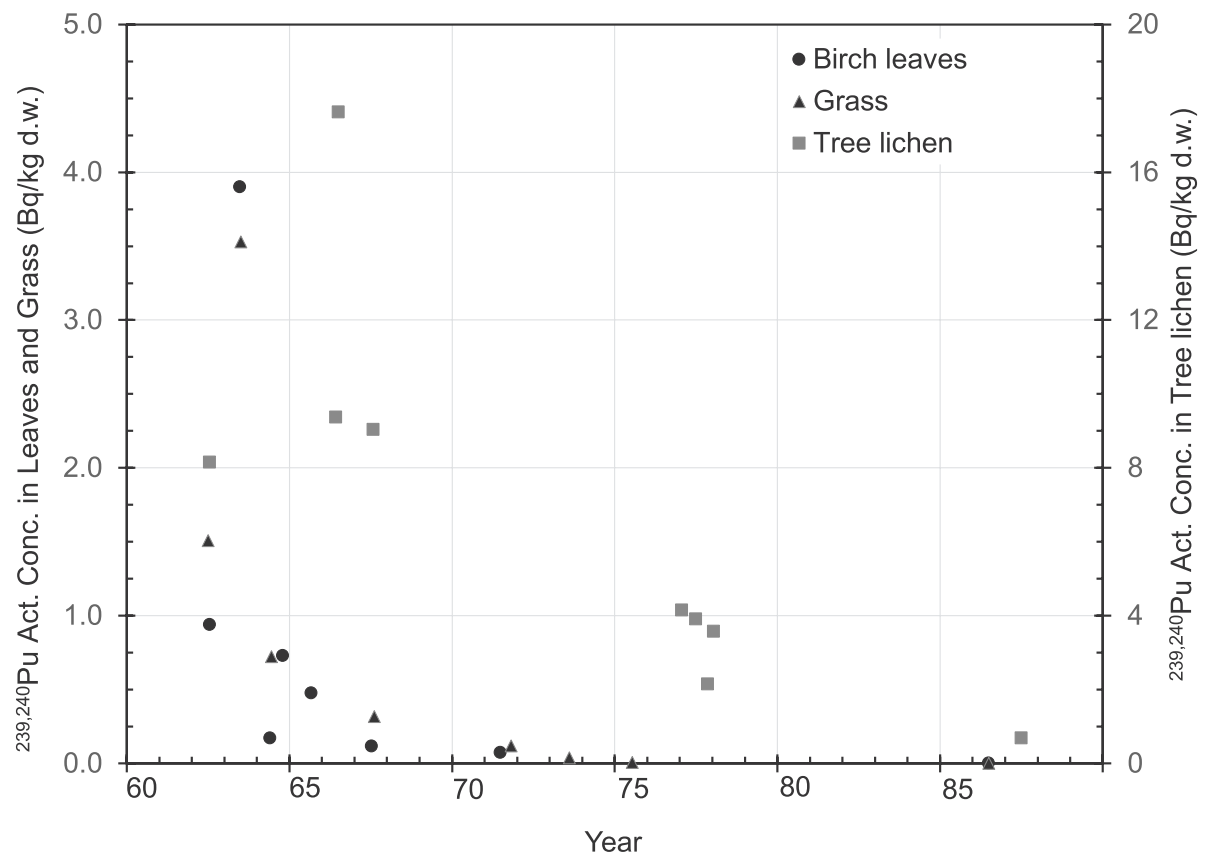

Fig. 4. ${ }^{239,240} \mathrm{Pu}$ in birch leaves (left vertical axis, black discs), grass (left vertical axis, black triangles) and tree lichen (right vertical axis, grey squares) in Finnish Lapland during 1962-1987 (Jaakkola et al., 1981; Paatero et al., 1998).

describing the long-term behavior of contamination in food chains. In this case it was observed that the biological half-life of plutonium in lichen varied between $480 \mathrm{~d}$ and $800 \mathrm{~d}$ (Jaakkola et al., 1981). In other words, the amount of plutonium in lichen decreases to half of the original amount in 16-27 months even though its removal by radioactive decay is negligible within the same time scale (the physical half-life of ${ }^{239} \mathrm{Pu}$ is over 24,000 years). This result is in agreement with the study of Paatero et al. (1998) where a biological half-life value of 730 days was obtained for plutonium in lichen.

The ${ }^{239,240} \mathrm{Pu}$ activity concentrations in reindeer tissues in Finnish
Lapland between 1963 and 1987 are depicted in Figs. 6 and 7 (Jaakkola et al., 1981; Paatero and Jaakkola, 1998). The highest concentrations are found in liver and the lowest ones in muscle. In 1977, the activity concentrations had decreased to a tenth of the maximum values in 1964-1966, $0.6 \mathrm{~Bq} / \mathrm{kg}$ fresh weight (f.w.), $0.037 \mathrm{~Bq} / \mathrm{kg}$ f.w., $0.03 \mathrm{~Bq} / \mathrm{kg}$ f.w., and $0.007 \mathrm{~Bq} / \mathrm{kg}$ f.w. in liver, lung, bone, and muscle, respectively. In kidney the ${ }^{239,240} \mathrm{Pu}$ activity concentrations were similar to those in lung and bone excluding a lone outlier. Due to the low Chernobyl-derived plutonium deposition in Finnish Lapland the ${ }^{239}$, ${ }^{240} \mathrm{Pu}$ activity concentration in reindeer liver stayed low after the 


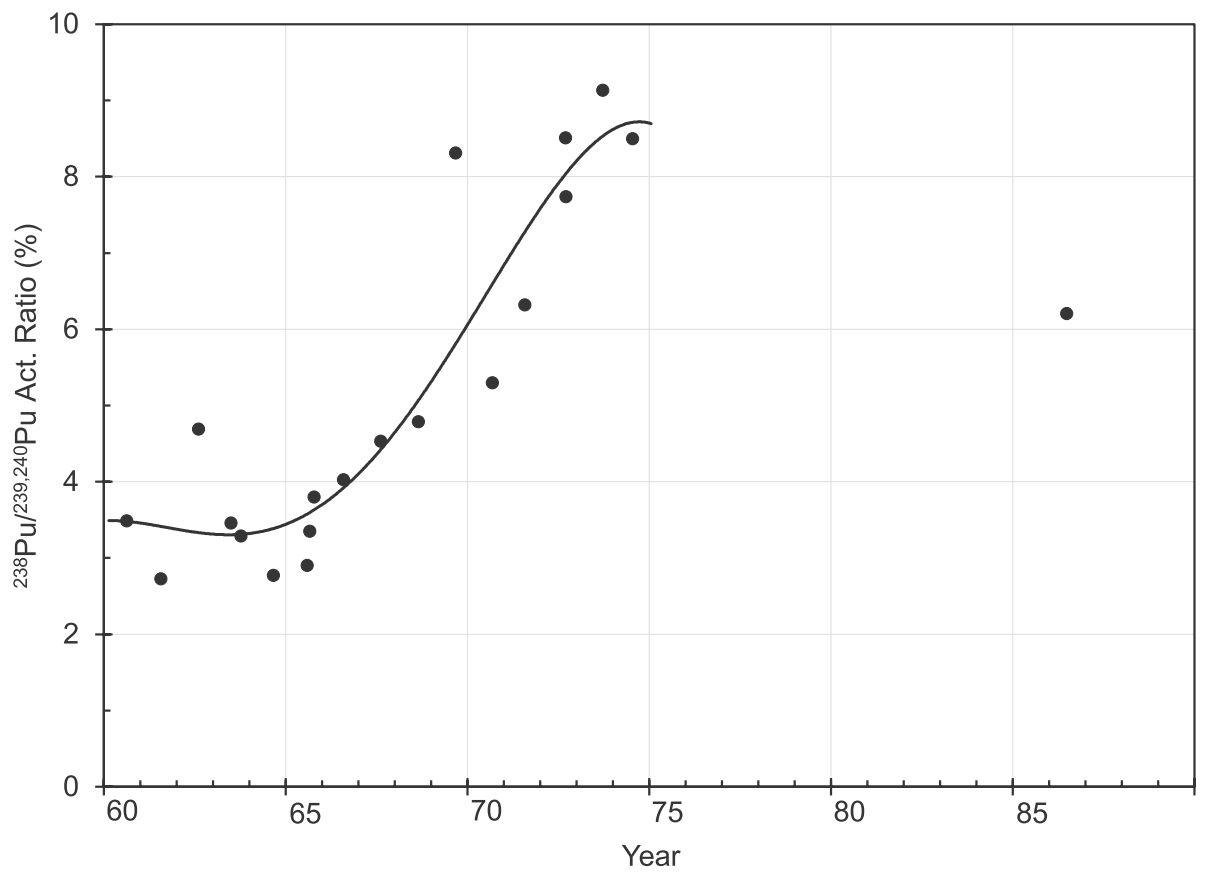

Fig. 5. ${ }^{238} \mathrm{Pu} /{ }^{239,240} \mathrm{Pu}$ activity ratio in lichen between 1960 and 1986 in Finnish Lapland (Miettinen, 1976; Paatero et al., 1998).

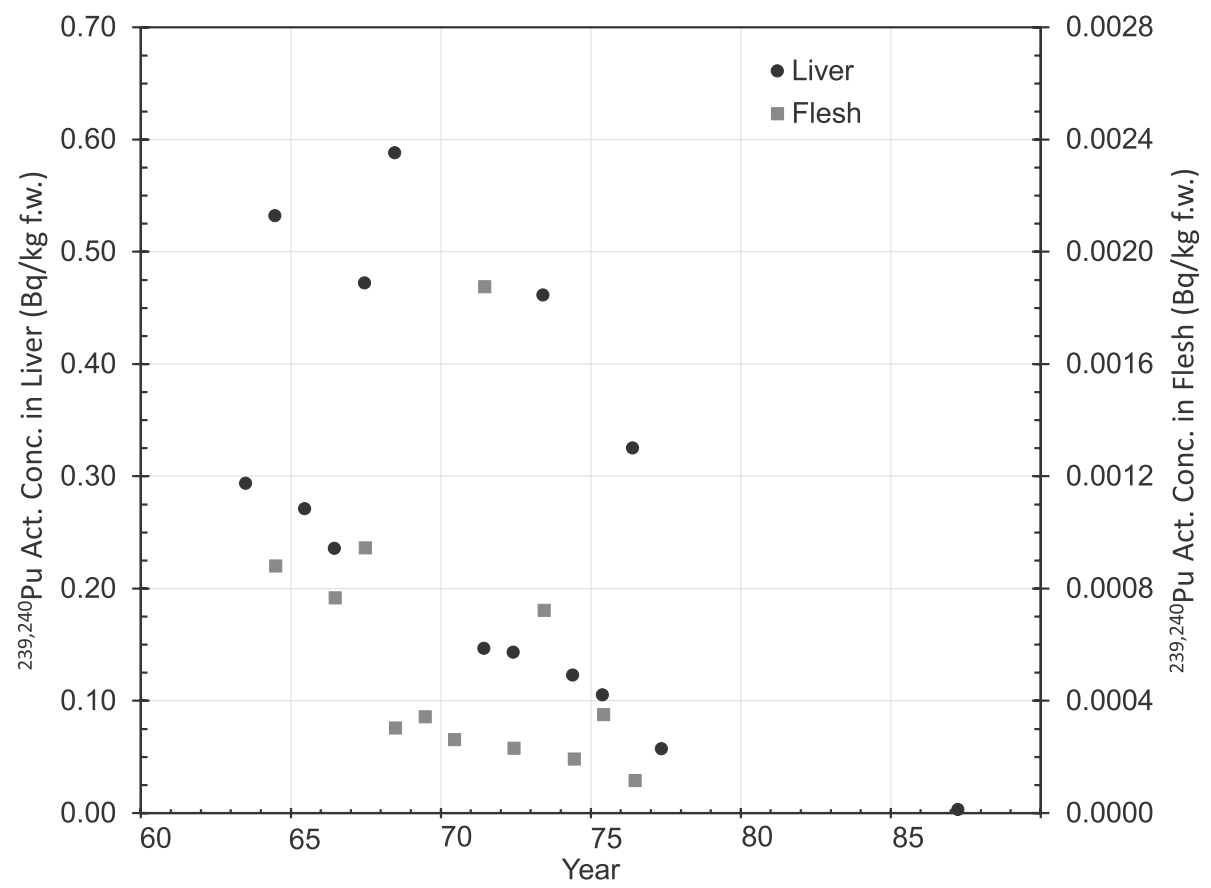

Fig. 6. ${ }^{239,240} \mathrm{Pu}$ in reindeer liver (left vertical axis, black disks) and flesh (right vertical axis, grey squares) in Finnish Lapland during 1963-1987 (Jaakkola et al., 1981; Paatero and Jaakkola, 1998).

Chernobyl accident. The variations of ${ }^{239,240} \mathrm{Pu}$ activity concentration in liver of different animals varied by more than an order of magnitude (Jaakkola et al., 1981). The reason for the large variation may be due to differences in lichen and tree lichen consumption of individual animals.

The distribution of plutonium in reindeer was studied by analyzing all major tissues of single reindeers (Fig. 8). In most cases over $60 \%$ of the plutonium was in the liver, and, thus, the plutonium content of reindeer depends mainly on the amount of plutonium in the liver. The plutonium content of bones varied between $10 \%$ and $40 \%$ from one case to another (Hakanen, 1981; Jaakkola et al., 1981).

A comparison of plutonium content of different tissues in reindeer and elk revealed that in 1964-1966 the plutonium contents of lungs were about the same (Keinonen et al., 1977; Miettinen et al., 1980). However, in liver and bone the ${ }^{239,240} \mathrm{Pu}$ concentration was approximately an order of magnitude higher in reindeer than in elk. This is explained by the fact that elks don't consume lichen as the reindeer do. Reindeer is the only large animal known to have received the major portion of its plutonium body burden from a dietary source instead of inhalation. The fraction of plutonium absorbed from the reindeer fodder along the gastrointestinal (GI) tract has been estimated to be $\left(\begin{array}{ll}4.0 & 0.4\end{array}\right)$ x $10^{5}$ (Jaakkola et al., 1981). In a later study of Paatero and Jaakkola (1998) a value of $3.0 \quad 10{ }^{5}$ was obtained. 


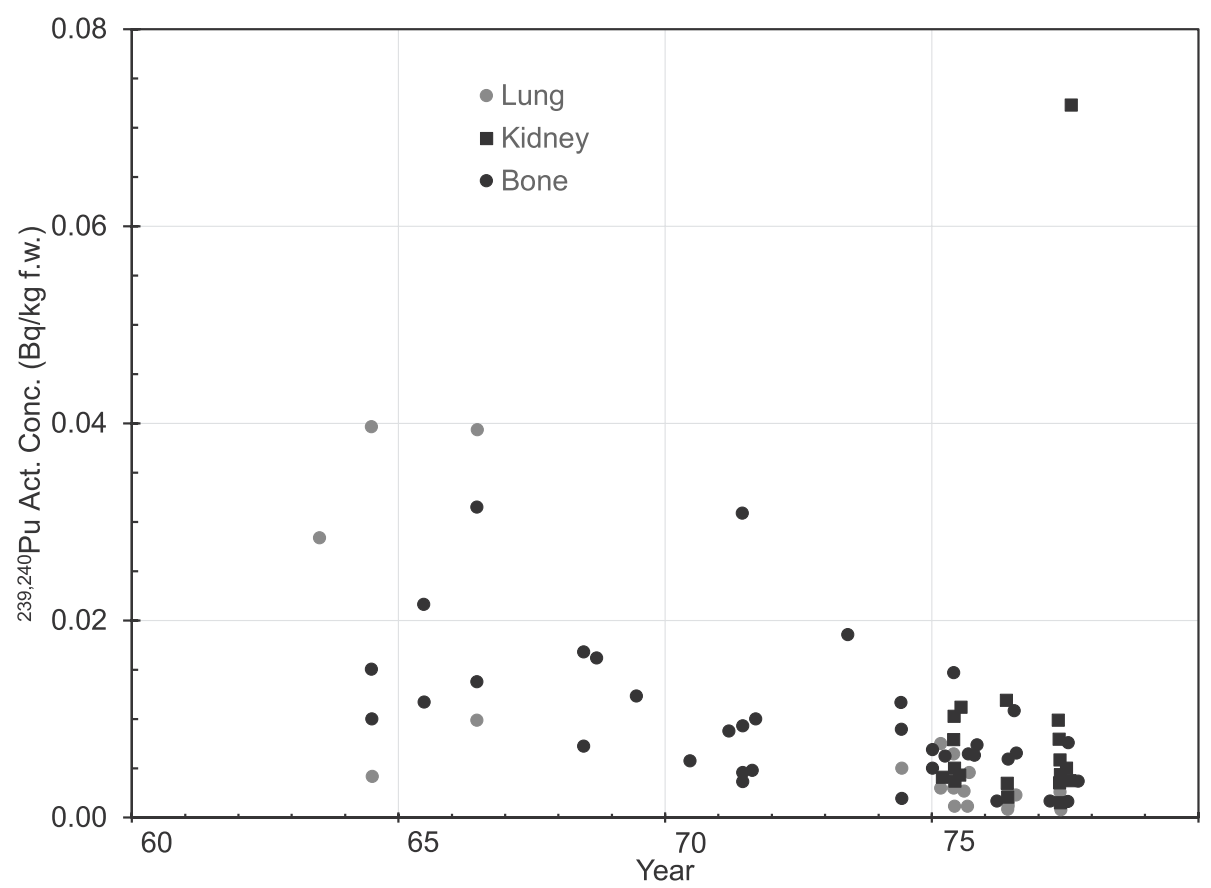

Fig. 7. ${ }^{239,240} \mathrm{Pu}$ in reindeer tissues (lung: grey disks, kidney: black squares, bone: black disks) in Finnish Lapland during 1963-1977 (Jaakkola et al., 1981).

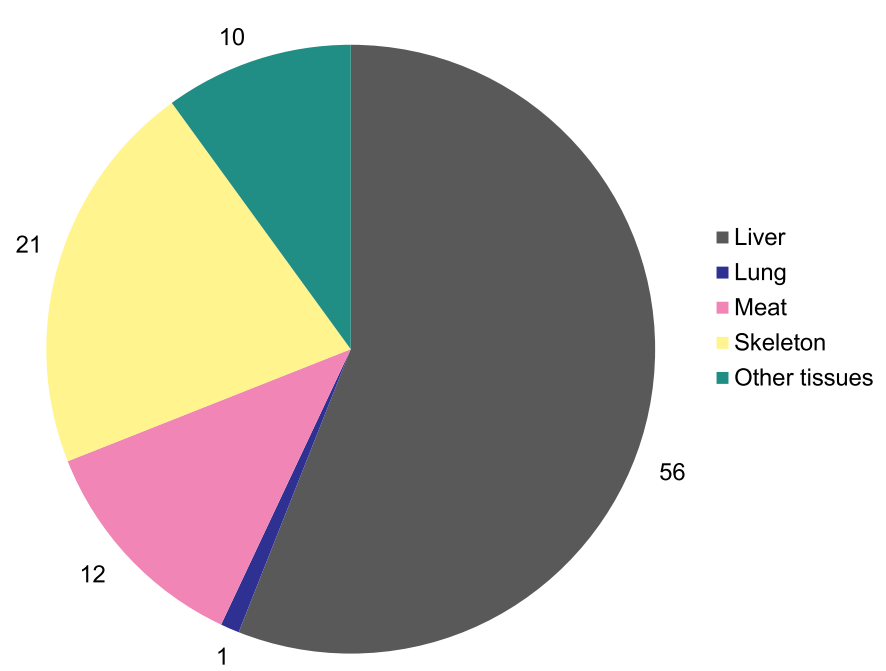

Fig. 8. Distribution of plutonium between different reindeer tissues (\%). This particular animal was a 13 years old male that was slaughtered in 1974 (Jaakkola et al., 1981).

The intake of plutonium by Sami people in Finland was assessed to be $1.5 \mathrm{~Bq} /$ year for men and $0.59 \mathrm{~Bq} /$ year for women in 1967 due to reindeer tissue consumption. In 1975 the corresponding figures were 0.37 $\mathrm{Bq} /$ year and $0.22 \mathrm{~Bq} /$ year (Jaakkola et al., 1981). About $70-80 \%$ of the plutonium intake was due to the consumption of reindeer liver. For comparison, the annual plutonium intake of residents in the New York City area, USA, was estimated to be $0.055 \mathrm{~Bq}$ /year in 1972. Plutonium content of humans was studied in the works of Mussalo-Rauhamaa (1981) and Mussalo-Rauhamaa et al. (1984). Autopsy samples of five Samis were dissected at the Central Hospital of Rovaniemi during 1977-1979. Plutonium content of the samples was analysed using radiochemical separation methods followed by semiconductor alpha spectrometry. The ${ }^{239,240} \mathrm{Pu}$ activity concentration in lung, liver and bone samples are depicted in Fig. 9. The highest activity concentrations are found in liver. There seems to be no clear relationship between the ${ }^{239,240} \mathrm{Pu}$ activity concentration and the profession of the person.
A significant portion (37-68\%) of the total amount of ${ }^{239,240} \mathrm{Pu}$ in human body is in liver (Fig. 10). The Sami whole body content doesn't differ from that of southern Finns. This is an interesting feature because the diet of Sami contains 10-15 times more plutonium than the diet of southern Finns. The fractional absorption factor of ${ }^{239,240} \mathrm{Pu}$ from the human gastrointestinal tract was calculated to be $8 \quad 10^{4}$.

\section{Americium}

Americium-241 contents of lichen samples collected in Finland (Fig. 11) are about a quarter of the corresponding ${ }^{239,240} \mathrm{Pu}$ contents. The ${ }^{241} \mathrm{Am} /{ }^{239,240} \mathrm{Pu}$ ratios are gradually increasing because of the ${ }^{241} \mathrm{Pu}$ decaying to ${ }^{241} \mathrm{Am}$, being $0.04-0.32$ in Finnish lichens during time period 1962-1974 (Harva, 1976). In the Chernobyl deposition this ratio will be 2.81 at its maximum in 2058 (Paatero et al., 1994). The biological half-life of ${ }^{241} \mathrm{Am}, 320$ days (Paatero et al., 1998) is shorter than that of plutonium. The ${ }^{241} \mathrm{Am} /{ }^{239,240} \mathrm{Pu}$ activity ratio in reindeer liver, 0.18 , is close to the values found in lichen (Jaakkola et al., 1981). However, in reindeer bones the ratio was 1.0 indicating a more efficient accumulation of americium into bones compared to the accumulation of plutonium. The same applies to reindeer lung (Paatero and Jaakkola, 1998). A GI absorption coefficient of $7.510^{4}$ for reindeer was observed. This indicates that americium is transferred from fodder to reindeer almost an order of magnitude more efficiently that plutonium. All these data indicate, that americium is more mobile in the biosphere compared with plutonium.

\section{Curium}

Only negligible amounts of curium isotopes were produced in the nuclear tests (Holm and Persson, 1978b). After the Chernobyl accident $0.550 .08 \mathrm{~Bq} / \mathrm{kg}$ d.w. of ${ }^{242} \mathrm{Cm}$ was found in lichen collected in Inari (Paatero, 2000). This was less than one per cent of the values observed in southwestern Finland. Even this small amount of ${ }^{242} \mathrm{Cm}$ was rather quickly removed from the lichen-reindeer-man food chain due to the short half-life of ${ }^{242} \mathrm{Cm}, 163$ days. Based on the average ${ }^{243,244} \mathrm{Cm} /{ }^{242} \mathrm{Cm}$ activity ratio of 0.0056 in lichen in southern Finland and the observed ${ }^{242} \mathrm{Cm}$ activity concentration one can calculate that the ${ }^{243,244} \mathrm{Cm}$ activity concentration in lichen in northern Finland was about $0.003 \mathrm{~Bq} / \mathrm{kg}$ d.w. 


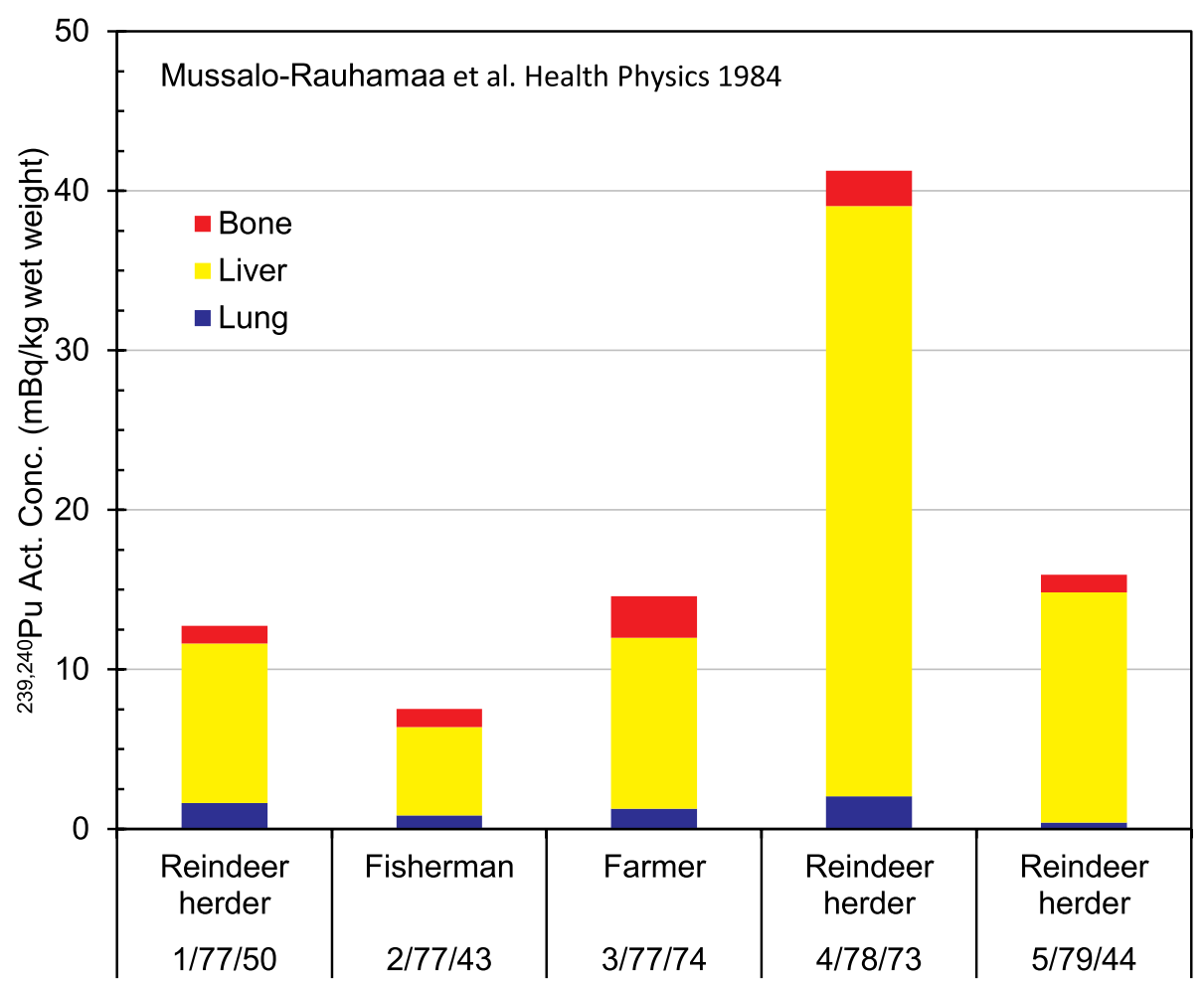

Fig. 9. ${ }^{239,240} \mathrm{Pu}$ activity concentration in lung, liver and bone of five Sami persons (Mussalo-Rauhamaa et al., 1984). The sample codes beneath the profession: Sample No./Year of death/Age.

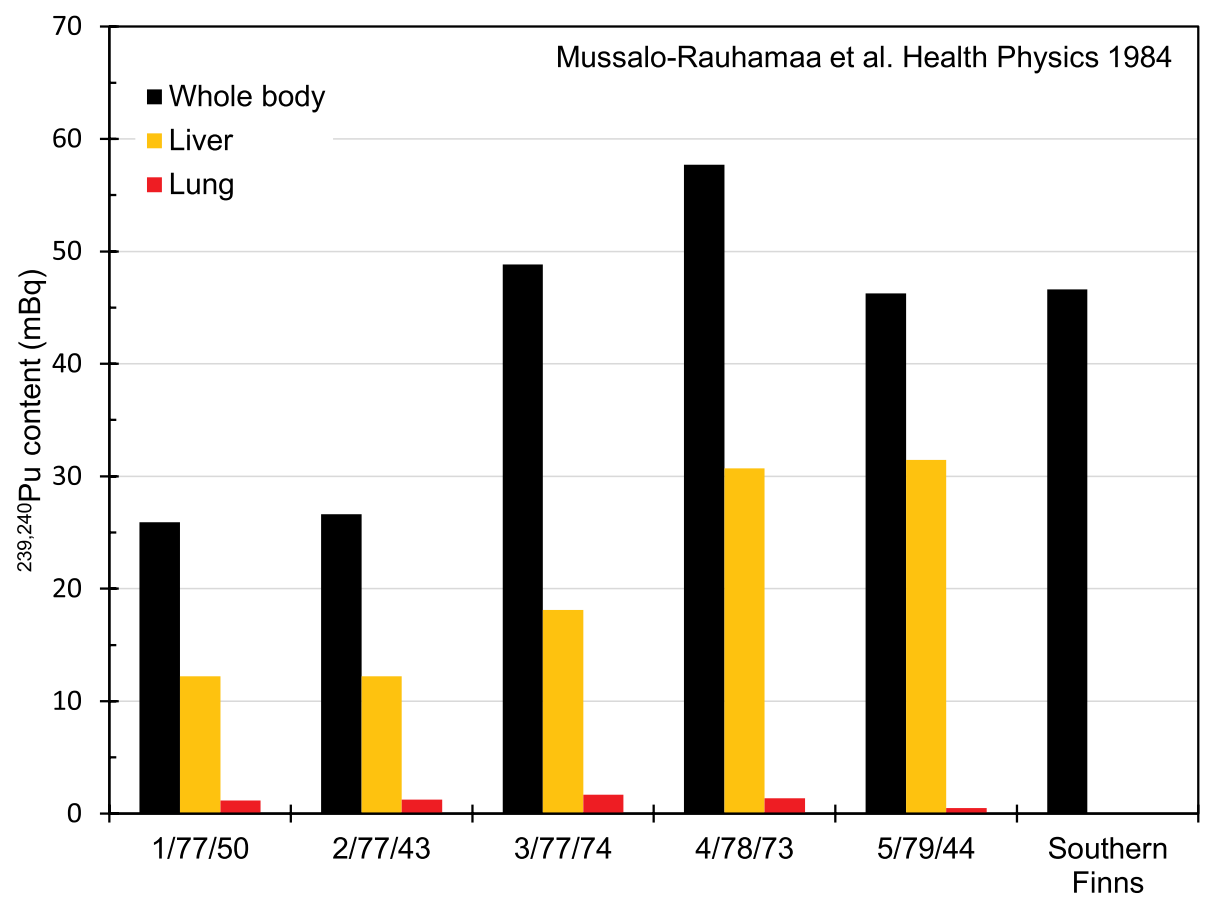

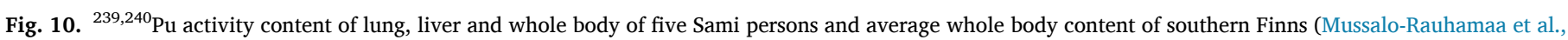
1984). The sample codes: Sample No./Year of death/Age.

(Paatero et al., 1998). The ${ }^{242} \mathrm{Cm}$ content of a grass sample collected in summer 1986 at Inari region, northern Finland was $0.11 \quad 0.03 \mathrm{~Bq} / \mathrm{kg} \mathrm{d}$. w. but the ${ }^{242} \mathrm{Cm}$ content of birch leaves remained under the detection limit of $0.10 \mathrm{~Bq} / \mathrm{kg}$ d.w. Due to the chemical similarity of curium and americium one can expect that the transfer of curium along the lichen-reindeer-man food chain is similar to that of americium.

\section{Neptunium}

Neptunium-237 is an extremely long-lived radionuclide with a halflife of 2.14 million years. Due to analytical difficulties, especially the lack of suitable tracers, it has gained very little attention within studies of environmental radioactivity. The only publication of environmental 


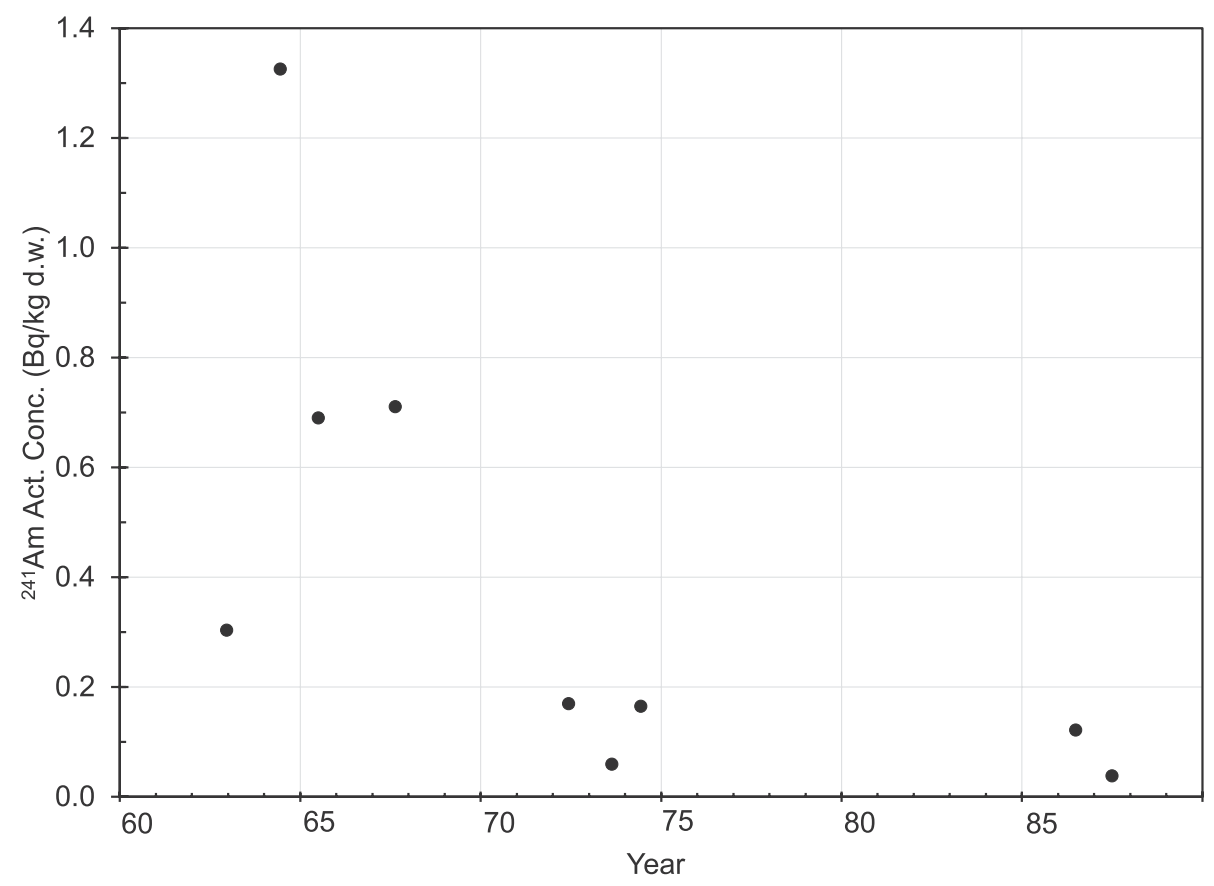

Fig. 11. ${ }^{241}$ Am in lichen in Finnish Lapland during 1962-1987 (Jaakkola et al., 1981; Paatero et al., 1998).

${ }^{237} \mathrm{~Np}$ in Finland is that of Salminen et al. (2009). In Rovaniemi and Inari the ${ }^{237} \mathrm{~Np}$ content of lichen was below detection limit, $<0.76 \mathrm{mBq} / \mathrm{kg} \mathrm{d}$. w. Lindahl et al. (2004) analysed two lichen samples collected in northern Sweden close to the Finnish-Swedish border. The ${ }^{237} \mathrm{~Np}$ activity contents of lichen samples from 1984 to 1987 were $10.9 \quad 0.9$ $\mathrm{mBq} / \mathrm{kg}$ and $1.60 \quad 0.13 \mathrm{mBq} / \mathrm{kg}$, respectively. Based on the observed ${ }^{238} \mathrm{Pu} /{ }^{239,240} \mathrm{Pu}$ activity ratio of $0.04 \quad 0.01$ in the 1987 sample it is evident that it contained practically no contamination from the Chernobyl accident.

In addition, a short-lived isotope ${ }^{239} \mathrm{~Np}\left(\mathrm{t}^{1 / 2} 2.4 \mathrm{~d}\right)$ was detected in mushroom (240 Bq/kg f.w.) and wild leafy vegetables (58 Bq/kg f.w.) in southern Finland after the Chernobyl accident (Rantavaara, 1987).

\section{Conclusions}

Considerable amounts of data concerning the transfer of transuranium elements along the subarctic food chain lichen-reindeer-man have been gathered during the last five decades. Globally this food chain is a rare one as there are very few other food chains that enrich radioactivity from deposition to man with a similar efficiency. But still, the amount of transuranium elements in humans is quite low compared to fission products and natural radionuclides. The lichen-reindeer-man food chain has been quite unique because it has allowed studies of the transfer of radionuclides into man in an actual environment without added tracers and test animals.

Luckily the Chernobyl accident affected significantly only the southernmost reindeer herding district of Halla. The accident timing effects on the deposition pattern has been studied with dispersion calculations. If the accident had happened only one day earlier than it actually did the resulting ${ }^{137} \mathrm{Cs}$ deposition in the Sami region would have been $20-50 \mathrm{kBq} / \mathrm{m}^{2}$, ten times more than the global weapons test fallout (Siljamo and Lahtinen, 2006). This would have ruined the reindeer husbandry and the associated culture for decades.

Despite the additional radionuclide intake of Sami population due to reindeer meat consumption the incidence rate of common cancers in Finland (e.g. prostate, breast and skin) has been traditionally less than within the Finland's main population (Soininen and Pukkala, 2016). This difference seems to fade away gradually. One reason may be related to the lifestyles. When the radioactivity studies began six decades ago many reindeer herding Samis were still living in a subsistence economy based on local reindeer meat, fish, game, berries etc. But slowly their nutrition habits have changed towards the main population's diet.

In the current situation the concentrations of transuranium elements decrease constantly in the environment, excluding ${ }^{241} \mathrm{Am}$ and ${ }^{237} \mathrm{~Np}$, the daughter and granddaughter nuclide of short-lived beta emitter ${ }^{241} \mathrm{Pu}$ $\left(\mathrm{t}^{1 / 2} 14.35 \mathrm{a}\right)$, which is abundant particularly from Chernobyl and Fukushima (nuclear power plant) accidents. In general, the environmental concentrations of transuranium radionuclides approach in many cases detection limits of the instruments. Natural radionuclides pose higher risk in respect to radiation dose and exposure in environment and along food chains, compared to the artificial transuranics. However, future situation is unknown. For maintaining emergency preparedness and effective radiation protection of vulnerable Arctic ecosystems, wellestablished, reliable and sensitive detection methods - both radioanalytical and instrumental - will be always needed and need to be improved for monitoring transuranium elements in the environment.

\section{Acknowledgements}

This work is part of the project "Food and health security in the Norwegian, Russian and Finnish border regions: linking local industries, communities and socio-economic impacts". Financial support for the project was received from EU/Kolarctic ENPI CBC programme managed by the Regional council of Lapland. The authors would like to acknowledge the numerous researchers who participated the lichen-reindeer-man studies before and during "The American project", especially late Academician Jorma K. Miettinen and Prof. Emer. Timo Jaakkola, for the pioneering work with subarctic radioecology in Finland.

\section{Appendix A. Supplementary data}

Supplementary data to this article can be found online at https://doi. org/10.1016/j.jenvrad.2019.106126.

\section{References}

Arctic Monitoring and Assessment Programme, 2010. AMAP Assessment 2009: Radioactivity in the Arctic. Arctic Monitoring and Assessment Programme, Oslo, Norway. 
Hakanen, M., 1981. Distribution of Plutonium in Tissues and Organs of Reindeer. Licenciate's thesis. Department of Radiochemistry, University of Helsinki (In Finnish).

Hakanen, M., Jaakkola, T., Korpela, H., 1984. Simultaneous determination of ${ }^{241} \mathrm{Pu}$, ${ }^{238} \mathrm{Pu}$ and ${ }^{239,240} \mathrm{Pu}$ in low activity environmental samples. Nucl. Instrum. Methods 223, 382-385.

Hanson, W.C., 1967. Cesium-137 in Alaskan lichens, caribou and eskimos. Health Phys. 13, 383-389.

Hardy, E.P., Krey, P.W., Volchok, H.L., 1973. Global inventory and distribution of fallout plutonium. Nature 241, 444-445.

Harva, K., 1976. Americium in Lichen in 1960-1976. Master's thesis. Department of Radiochemistry, University of Helsinki (in Finnish).

Hasunen, K., Mottonen, H., 1976. Food Consumption and Intake of Iron and Potassium by Finnish Lapps in 1971 and 1976. Paper No. 76. Annual Report 1976. Department of Radiochemistry, University of Helsinki.

Holm, E., Persson, B.R.R., 1975. Fall-out plutonium in Swedish reindeer lichen. Health Phys. 29, 43-51.

Holm, E., Persson, B.R.R., 1978. Biophysical aspects of Am-241 and Pu-241 in the environment. Radiat. Environ. Biophys. 15, 261-276.

Holm, E., Persson, B.R.R., 1978. Global fallout of curium. Nature 273, 289-290.

Jaakkola, T., 1969. Analysis of iron-55 produced by nuclear tests and its enrichment in Finnish lapps. Ann. Acad. Sci. Fenn. Ser. A II Chem. 150.

Jaakkola, T., Harva, K., Keinonen, M., Hakanen, M., 1978. Studies on the behaviour of transuranic elements in plants. In: Radioactive Foodchains in the Subarctic Region. Progress Report for the Period Nov. 15, 1977 - Nov. 14, 1978. Department of Radiochemistry, University of Helsinki (paper No. 96). U.S. Department of Energy contract EY-76-C-02-3011.A002. Report C-02-3011.

Jaakkola, T., Keinonen, M., Hakanen, M., Miettinen, J.K., 1981. Investigations of the transfer of plutonium and americium from plants to reindeer and man in Finnish Lapland. In: Wrenn, M.E. (Ed.), Actinides in Man and Animals. Proceedings of the Snowbird Actinide Workshop, 15-17 October 1979. RD Press, Salt Lake City, USA, pp. 509-524.

Jaakkola, T., Miettinen, J.K., Tulikoura, J., Mussalo, H., 1975. The plutonium foodchain lichen-reindeer-man. In: Third European Congress of the International Radiation Protection Association, Amsterdam, Netherlands, 13-16 May 1975. J1/Health Phys. 29 (1975) abstract 640.

Jokelainen, A., Pekkarinen, M., Roine, P., Miettinen, J.K., 1962. The diet of Finnish Lapps. Z. Ernahr.Wiss. 3, 110-117.

Jokelainen, A., 1965. Diet of the Finnish Lapps and its caesium-137 and potassium contents. Acta Agral. Fenn. 103.

Kauranen, P., Miettinen, J.K., 1969. ${ }^{210} \mathrm{Po}$ and ${ }^{210} \mathrm{~Pb}$ in the arctic foodchain and the natural radiation exposure of lapps. Health Phys. 16, 287-295.

Keinonen, M., Jaakkola, T., Miettinen, J.K., 1977. Plutonium in reindeer in Finnish Lapland during 1963-1976. In: Uptake of plutonium from food. paper No 86 from technical progress report Aug. 15, 1976 - Nov. 14, 1977 on radioactive foodchains in the subarctic environment. Contract CH E (11-1)-3011 from the US ERDA (Energy Research and Development Administration). Department of Radiochemistry, University of Helsinki.

Krey, P.W., 1967. Atmospheric burnup of a plutonium-238 generator. Science 158, 769-771.

Lindahl, P., Roos, P., Eriksson, M., Holm, E., 2004. Distribution of Np and Pu in Swedish lichen samples (Cladonia stellaris) contaminated by atmospheric fallout. J. Environ. Radioact. 73, 73-85.

Miettinen, J.K., Hasanen, E., 1967. ${ }^{137}$ Cs in Finnish and other Finns in 1962-6. In: Åberg, B., Hungate, F.P. (Eds.), Radioecological Concentration Processes. Proceedings of an International Symposium Held in Stockholm, 25-29 April, 1966. Pergamon Press, Oxford, pp. 221-231.

Miettinen, J.K., Jokelainen, A., Roine, P., Liden, K., Naversten, Y., $1963 .{ }^{137} \mathrm{Cs}$ and potassium in people and diet - a study of Finnish lapps. Ann. Acad. Sci. Fenn. Ser. A II Chem. 120.

Miettinen, J.K., Mussalo, H., Hakanen, M., Jaakkola, T., Keinonen, M., Tahtinen, P., 1980. Distribution of plutonium and americium in human and animal tissues after chronic exposures. In: Radiation Protection. A Systematic Approach to Safety. Proceedings of the 5th Congress of the International Radiation Protection Society, Jerusalem, March 1980, vol. 2. Pergamon Press Ltd, Oxford, UK, pp. 1049-1052.

Mussalo-Rauhamaa, H., 1981. Accumulation of Plutonium from Fallout in Southern Finns and Lapps. Ph.D. Thesis. Report Series in Radiochemistry 4/1981. Department of Radiochemistry, University of Helsinki.
Mussalo-Rauhamaa, H., Jaakkola, T., Miettinen, J.K., Laiho, K., 1984. Plutonium in Finnish Lapps. An estimate of the gastrointestinal absorption of plutonium by man based on a comparison of the plutonium content of Lapps and southern Finns. Health Phys. 46, 549-559.

Miettinen, J.K., 1976. Radioactive foodchains in the subarctic environment. In: Progress Report for Period Aug. 15, 1975-Aug. 14, 1976. Department of Radiochemistry, University of Helsinki.

Paatero, J., Jaakkola, T., Reponen, A., 1994. Determination of the ${ }^{241} \mathrm{Pu}$ deposition in Finland after the Chernobyl accident. Radiochim. Acta 64, 139-144.

Paatero, J., Jaakkola, T., 1998. Transfer of plutonium, americium and curium from fallout into reindeer after the Chernobyl accident. Boreal Environ. Res. 3, 181-189.

Paatero, J., Jaakkola, T., Kulmala, S., 1998. Lichen (sp. Cladonia) as deposition indicator for transuranium elements investigated with the Chernobyl fallout. J. Environ. Radioact. 38, 223-247.

Paatero, J., 2000. Deposition of Chernobyl-Derived Transuranium Nuclides and ShortLived Radon-222 Progeny in Finland. Finnish Meteorological Institute, Helsinki. Contributions No. 28.

Paatero, J., Jaakkola, T., Ikaheimonen, T.K., 2002. Regional distribution of chernobylderived plutonium in Finland. J. Radioanal. Nucl. Chem. 252, 407-412.

Paatero, J., Jaakkola, T., Ikaheimonen, T.K., 2006. Deposition of chernobyl-derived plutonium in Finland. In: Ikaheimonen, T.K. (Ed.), Radioactivity in the Environment in Finland - 20 Years since Chernobyl. Symposium in Helsinki 25.-26.4.2006. STUKA217. Sateilyturvakeskus, Helsinki, pp. 178-182 (In Finnish).

Paatero, J., Saxen, R., Buyukay, M., Outola, I., 2010. Overview of strontium-89,90 deposition measurements in Finland 1963-2005. J. Environ. Radioact. 101, 309-316.

Paatero, J., Vira, J., Siitari-Kauppi, M., Hatakka, J., Holmen, K., Viisanen, Y., 2012. Airborne fission products in the high Arctic after the Fukushima nuclear accident. J. Environ. Radioact. 114, 41-47.

Rantavaara, A., 1987. Radioactivity of Vegetables and Mushrooms in Finland after the Chernobyl Accident in 1986. Supplement 4 to Annual Report STUK-A55. STUK-A59. Finnish Centre for Radiation and Nuclear Safety, Helsinki, Finland.

Rissanen, K., Rahola, T., 1989. Cs-137 concentration in reindeer and its fodder plants. Sci. Total Environ. 85, 199-206.

Salminen, S., Paatero, J., Jaakkola, T., Lehto, J., 2005. Americium and curium deposition in Finland from the Chernobyl accident. Radiochim. Acta 93, 771-779.

Salminen, S., Paatero, J., 2009. Concentrations of ${ }^{238} \mathrm{Pu},{ }^{239}{ }^{240} \mathrm{Pu}$ and ${ }^{241} \mathrm{Pu}$ in the surface air in Finnish Lapland in 1963. Boreal Environ. Res. 14, 827-836.

Salminen, S., Paatero, J., Roos, P., Helariutta, K., 2009. ${ }^{237} \mathrm{~Np}$ in peat and lichen in Finland. J. Radioanal. Nucl. Chem. 281, 405-413.

Salminen-Paatero, S., Nygren, U., Paatero, J., $2012 .{ }^{240} \mathrm{Pu} /{ }^{239} \mathrm{Pu}$ mass ratio in environmental samples in Finland. J. Environ. Radioact. 113, 163-170.

Salminen-Paatero, S., Jaakkola, T., Paatero, J., 2014. ${ }^{241} \mathrm{Pu}$ and ${ }^{241} \mathrm{Pu} /{ }^{239}{ }^{240} \mathrm{Pu}$ activity ratio in environmental samples from Finland as evaluated by the ingrowth from ${ }^{241}$ Am. Boreal Environ. Res. 19, 51-65.

Salminen-Paatero, S., Vira, J., Paatero, J., 2019. Measurements and Modelling of Airborne Plutonium in Subarctic Finland between 1965 and 2011 (submitted for publication).

Salo, A., Alha, A., Miettinen, J.K., 1963. Caesium-137 in the blood of the Finnish lapps. Nature 200, 1119-1120.

Siljamo, P., Lahtinen, J., 2006. 20 Years since the Chernobyl accident. In: How Would the Dispersion of Radioactive Substances Be Forecasted Today? Alara 2/2006, pp. 18-19 (In Finnish).

Soininen, L., Pukkala, E., 2016. Follow-up of cancer incidence among Finnish Sami 19792010. Int. J. Circumpolar Health 75, 73-73.

Svensson, G.K., Liden, K., 1965. The transport of ${ }^{137} \mathrm{Cs}$ from lichen to animal and man. Health Phys. 11, 1393-1400.

Tulikoura, J., Jaakkola, T., Miettinen, J.K., 1974. Plutonium in lichen in Finland during 1960-1973. In: Radioactive Foodchains in the Subarctic Environment. Technical Progress Report for the Period Aug. 15, 1973 - Aug. 14, 1974. U.S. Atomic Energy Commission Contract CH at (11-1)-3011. Department of Radiochemistry, University of Helsinki.

Tuominen, Y., Jaakkola, T., 1973. Absorption and accumulation of the mineral elements and radioactive nuclides. In: Ahmadjian, V., Hale, M.E. (Eds.), The Lichens. Academic Press, New York, USA, pp. 185-223. 